\title{
The effect Of Employee Engagement and Emotional Intelligent on Organizational Commitment by Job Satisfaction as Mediate Variable Case in Employee Of Islamic Education Institution
}

\author{
Fatmah Bagis $^{1 *)}$, Akhmad Darmawan ${ }^{2)}$, Mastur Mujib Ikhsani ${ }^{3)}$, Purnadi ${ }^{4)}$ \\ ${ }^{1,2,3,4}$ Fakultas Ekonomi dan Bisnis, Universitas Muhammadiyah Purwokerto \\ *Email correspondence: fatmahbagis2014@gmail.com
}

\begin{abstract}
This study explains the effect of employee engagement and emotional intelligence on organizational commitment with the mediating variable is job satisfaction. This study uses a case study method on employees of an Islamic educational institution in Purwokerto. Respondents in this study were 100 employees from management level to staff level. The analysis PLS (Partial Least Square) was used in this study. Based on the research results, Employee Engagement does not have a significant effect on Job Satisfaction, Emotional Intelligence has a significant effect on Job Satisfaction. Besides, Job Satisfaction and Emotional Intelligence do not have a significant effect on organizational commitment. Employee involvement has a significant effect on organizational commitment. As well as other research results show that Job Satisfaction cannot mediate between Employee Engagement and Organizational Commitment, but it also cannot mediate Emotional Intelligence in Organizational Commitment.
\end{abstract}

Keywords: employee engagement, emotional intelligence, job satisfaction, and organizational commitment.

Citation suggestions: Bagis, F., Darmawan, A., Ikhsani, M. M., \& Purnadi. (2021). The effect Of Employee Engagement and Emotional Intelligent on Organizational Commitment by Job Satisfaction as Mediate Variable Case in Employee Of Islamic Education Institution. Jurnal Ilmiah Ekonomi Islam, 7(01), 460-466. doi:http://dx.doi.org/10.29040/jiei.v7i1.2132

DOI: http://dx.doi.org/10.29040/jiei.v7i1.2132

\section{INTRODUCTION}

One of the important components of an organization is human resources. (Mathis, R, 2011) states that every organization places human resources as a special part that must be considered, meaning that the organization must be able to see the talents of an employee to improve performance and as an opportunity to create a greater organizational competitive advantage.

According to Snell, S, (2013), human resources are thoughts that integrate the abilities and physical strengths of individuals who are built so that they are able to compete to face increasingly fierce competition.

Competition and high quality that is owned, raise various kinds of problems in the organization, namely how an organization is able to retain employees with high commitment to the organization. (Bagis et al.,
2019) stated that human resource management is one of the main roles for organizational success.

(Robbins, 2006) states that organizational commitment is an attitude in which employees reflect on their feelings of liking or not to the organization. In general, organizational commitment can be defined as the identification and involvement of someone who is relatively very strong in the organization.

Factors that affect organizational commitment include employee involvement, organizational culture and emotional intelligence as well as employee satisfaction with the work done. These factors must be considered by the company so that employees have high organizational commitment.

The first factor in improving organizational commitment one of which is the involvement of employees (employee engagement) (Schaufeli, W. B, 2003) in Bakker and Leiter According to (Schaufeli, $\mathrm{W} . \mathrm{B}, 2003$ ) in (Bakker, 2010), "the sense of 


\section{Jurnal Ilmiah Ekonomi Islam, 7(01), 2021, 461}

energetic and effective connection that employees have in their work activities, and their ability not to properly store their jobs.

A supervising mind state work engagement with a positive and satisfying job that pays attention to indicators such as passion, dedication, and absorption.". This can be interpreted that employees who are bound have energy and have an effective relationship with their work activities and they feel able to complete all job demands. Attachment is defined as something that is associated with work that is positive and is characterized by enthusiasm, dedication and absorption.

The second factor that can affect organizational commitment is emotional intelligence. According to S. Taylor (2014), emotional intelligence is the ability to recognize one's own feelings and feelings of others, to motivate oneself, and to cultivate one's own emotions in relation to others.. (Goleman, 2005) states that emotional intelligence has the same power as intellectual intelligence, sometimes more powerful than intellectual intelligence. It can be ascertained that intellectual intelligence only contributes as much as $20 \%$ of its impact on a person's success, while the remaining $80 \%$ which determines the effect is from other factors. It cannot be denied that emotional intelligence is very important and can influence organizational commitment.

Another factor that affects organizational commitment is job satisfaction. (S Taylor, 2014), who argued that job satisfaction is a person's behavior towards the work they have. That way employee productivity can be increased by making employees in an organization feel satisfied, empowered by the organization, and fulfilling all their social needs. Employees who have a job satisfaction level that are high will show high concern for the organization, from which the desire to remain in the organization will emerge.

This study aims to determine how the relationship between employee involvement, organizational culture, and emotional intelligence on organizational commitment is mediated by job satisfaction variables. This research was created as a continuation of previous research that was related and has been carried out by researchers related to employees at the Islamic Education Institute in Purwokerto. This research is quite unique because it examines four variables, namely employee involvement, emotional intelligence, job satisfaction, and organizational commitment in one research method.

Based on the initial description and research objectives, the hypotheses that we can formulate are as follows:

H1: Employee involvement has a positive effect on Job Satisfaction.

$\mathrm{H} 2$ : Emotional Intelligence has a positive influence on Job Satisfaction

H3: Job satisfaction has a positive influence on Organizational Commitment

H4: Employee involvement has a positive effect on Organizational Commitment

H5: Emotional Intelligence has a positive influence on Organizational Commitment

H6: Employee Engagement and Organizational Commitment can be mediated by Job Satisfaction

H7: Emotional Intelligence and Organizational Commitment can be mediated by Job Satisfaction

\section{METHOD}

The quantitative approach is used in this research. The survey method used in this study was a questionnaire that was filled in indirectly by the employees of Islamic education institutions in Purwokerto.The questionnaire was collected from 100 employees from management level to staff level. Partial Least Square (PLS) analysis is an analysis of the data used in this study.

a. Employee Engagement

Employee engagement is the intensity where individuals are actively involved in their work, identify themselves psychologically with their work, and realize that their work performance is important for their self-esteem (Sari et al., 2019). (Schaufeli, W. B, 2003) in (Bakker, 2010), employees who have an energy bond and an effective relationship with a work activity and feel able to complete all job demands. This attachment is a positive thing related to work, and the characteristics of vigor, dedication, and absorption.

b. Emotional intelligence

(Gardner, 2013) states that emotional intelligence is the ability to understand other people by motivating them, knowing how they work, and working hand in hand with intelligence. Emotional intelligence is a correlative ability, but it leads inward. This ability will form an accurate and self-referencing self-model. In addition, the 
ability to use capital as a tool to live life effectively.

c. Job satisfaction

General job satisfaction can be interpreted as a positive or negative attitude from an employee towards his job. (Bagis et al., 2018). Job satisfaction is the attitude and feelings of employees towards their work and working conditions. Feelings related to work that contain aspects such as wages or salaries.

d. Organizational Commitment.

General organizational commitment can be interpreted as a condition that is shared by all members of the organization in accordance with the new and the goals to be achieved. Organizational Commitment reflects the degree to which individuals internalize or monitor relationships across organizations or

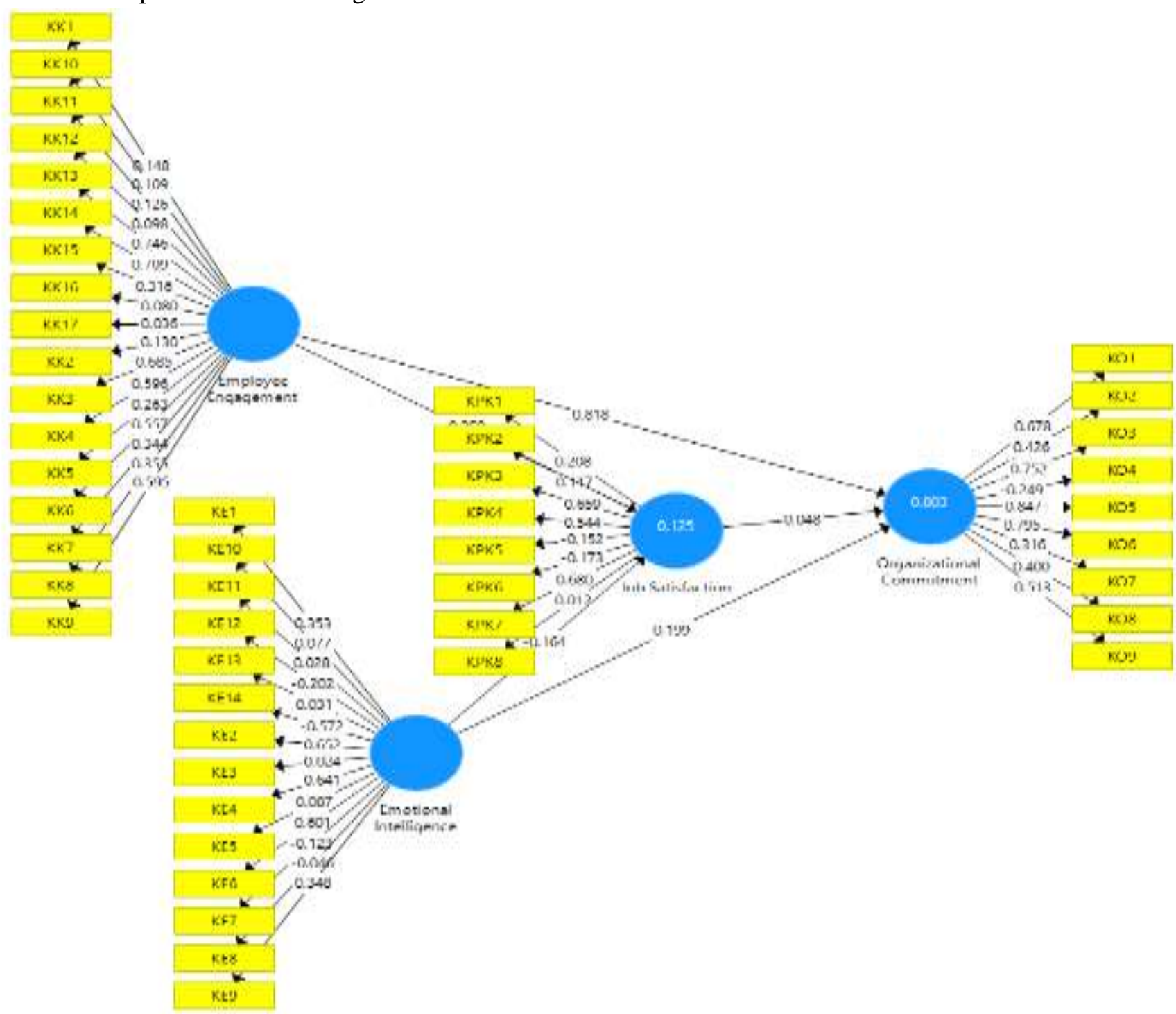

The results of PLS Version 3.0 on first-round regarded the effect of employee engagement and perspectives. (Bagis et al., 2020). In addition, organizational commitment is the psychological attachment that a person feels to the organization.

\section{RESULTS AND DISCUSSION}

(Chin, 1998) et (Ghozali, Imam, 2015) stated to assess the convergent validity of the loading factor value above $0.50-0.60$ is considered sufficient to scale. Based on the result of Average Variance Extra (AVE) score on emotional intelligence, employee engagement, job satisfaction, and organizational commitment are less than 0.50 so the research analysis is continued in the second round. The result of the composite reliability value on emotional intelligence and job satisfaction was also less than 0.70 so the research analysis was continued in the second round. fulfill the initial stages of developing a measurement 
a. Reliability and Validity

Table 1. Construct Reliability and Validity

\begin{tabular}{lcc}
\hline & $\begin{array}{c}\text { Composite } \\
\text { Reliability }\end{array}$ & $\begin{array}{c}\text { Average Variance } \\
\text { Exctracted (AVE) }\end{array}$ \\
\hline $\begin{array}{l}\text { Emotional } \\
\text { Intilligence }\end{array}$ & 0.789 & 0.556 \\
\hline Employee & 0.840 & 0.520 \\
Engagement & & 0.581 \\
\hline Job Satisfaction & 0.731 & 0.556 \\
\hline $\begin{array}{l}\text { Organizational } \\
\text { Commitment }\end{array}$ & 0.858 & \\
\hline Structural & &
\end{tabular}

The result of convergent validity (loading factor) in the third round, the loading factor value for all indicator is more than 0.50 so it can be concluded that the model is valid, because has met the requirements of convergent validity. The composite reliability value for all the variables studied had met the criteria.

b. Structural Model Analysis

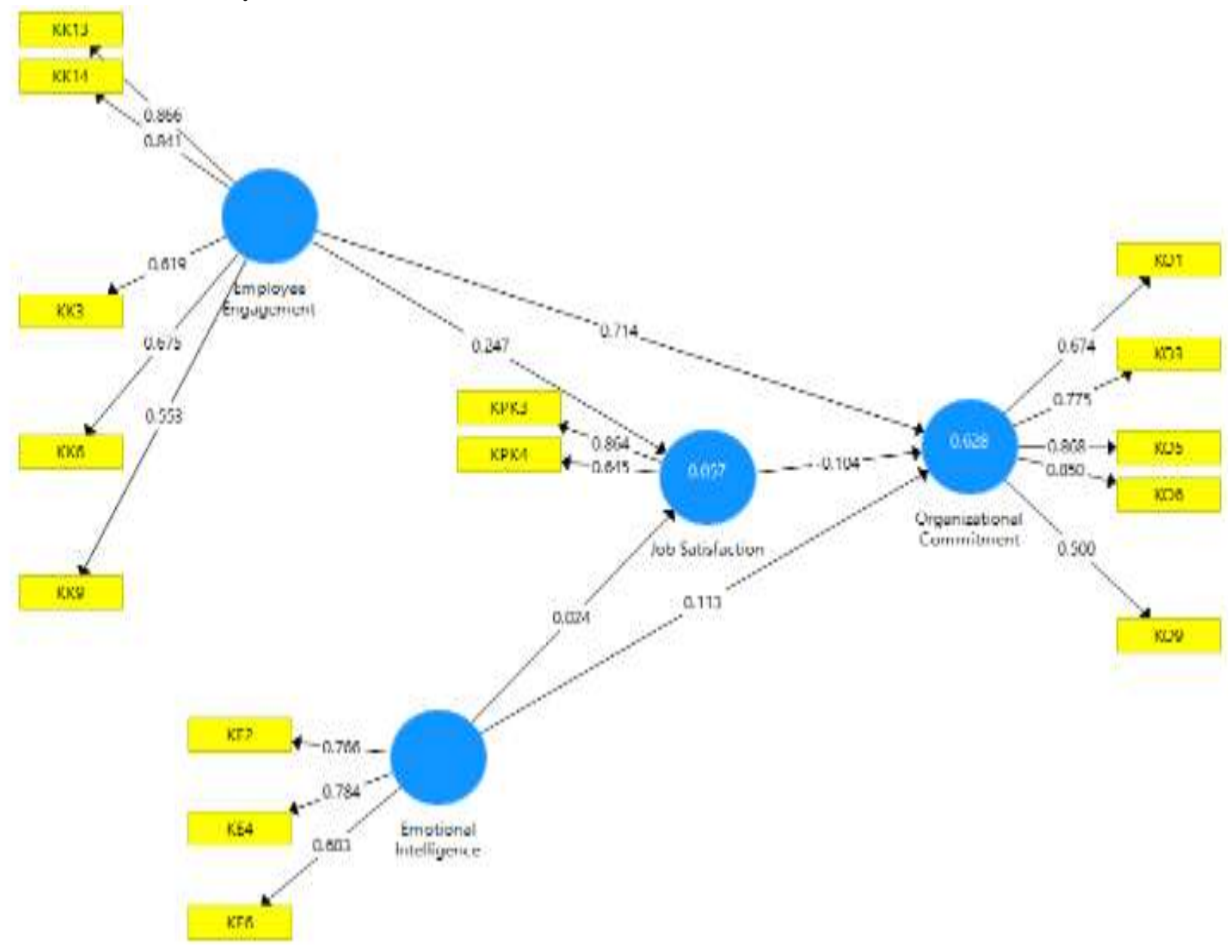

The results above are about the effect of employee engagement and emotional intelligence on organizational commitment through job satisfaction. Based on the picture above, it can be seen that the R2 value is 0.620 . This shows that the factors of employee engagement, emotional intelligence, and job satisfaction affect organizational commitment by $62.8 \%$. While the R2 value of 0.057 indicates that employee engagement and emotional intelligence variables affect job satisfaction by $5.7 \%$. The analysis of the structural model is carried out by evaluating the estimation results of the coefficient parameters and the level of significance. The test results for the significance of the path coefficient of each variable can be seen in Table 2 and indirect effect in Table 2. 
Jurnal Ilmiah Ekonomi Islam, 7(01), 2021, 464

Table 2. Parameter Coefficient and Statistical Values

\begin{tabular}{lccccc}
\hline & $\begin{array}{c}\text { Original } \\
\text { Sample }(\mathrm{O})\end{array}$ & $\begin{array}{c}\text { Sample Mean } \\
(\mathrm{M})\end{array}$ & $\begin{array}{c}\text { Standard Deviation } \\
(\mathrm{STDEV})\end{array}$ & $\begin{array}{c}\text { TStatistics } \\
(\mathrm{O} / \mathrm{STDEV})\end{array}$ & P Value \\
\hline $\begin{array}{l}\text { Employee Engagement => Job } \\
\text { Satisfaction }\end{array}$ & -0.247 & -0.267 & 0.094 & 2.639 & 0.009 \\
\hline $\begin{array}{l}\text { Emotional Intelligence => Job } \\
\text { Satisfaction }\end{array}$ & 0.024 & 0.022 & 0.111 & 0.218 & $\mathbf{0 . 8 2 8}$ \\
\hline $\begin{array}{l}\text { Job Satisfaction => } \\
\text { Organizational Commitment }\end{array}$ & -0.104 & -0.101 & 0.065 & 1.604 & $\mathbf{0 . 1 0 9}$ \\
$\begin{array}{l}\text { Employee Engagement => } \\
\text { Organizational Commitment }\end{array}$ & 0.714 & 0.723 & 0.097 & 7.382 & 0.000 \\
\hline $\begin{array}{l}\text { Emotional intellgence => } \\
\text { Organizational Commitment }\end{array}$ & 0.113 & 0.115 & 0.106 & 1.068 & $\mathbf{0 . 2 8 6}$ \\
\hline
\end{tabular}

Based on the table above, the original sample values indicated that the relationship can lead to positive or negative effects. The hypothesis will be accepted when the P-Value $<0.05$. The PLS shows that employee engagement has a significant effect on job satisfaction, and the first hypothesis which states that employee engagement has a positive effect on job satisfaction, then the first hypothesis is accepted.

The results showed that emotional intelligence has no significant effect on job satisfaction, and the second hypothesis states that emotional intelligence has a positive significant effect on job satisfaction, so that the second hypothesis is rejected. Based on the results of the study also shows that job satisfaction does not have a significant effect on organizational commitment, and the third hypothesis which states that job satisfaction has a positive significant effect on organizational commitment, so that the third hypothesis is rejected.

The results also showed that employee engagement had a significant influence on organizational commitment, so that the fourth hypothesis which stated that employee engagement had a significant positive effect on organizational commitment, so that the fourth hypothesis was accepted. The results showed that emotional intelligence did not have a significant effect on organizational commitment, and the fifth hypothesis which stated that emotional intelligence had a positive and significant effect on organizational commitment, so that the fifth hypothesis was rejected.

Table 3. Specific Indirect Effect

\begin{tabular}{lccccc}
\hline & $\begin{array}{c}\text { Original } \\
\text { Sample }(\mathrm{O})\end{array}$ & $\begin{array}{c}\text { Sample Mean } \\
(\mathrm{M})\end{array}$ & $\begin{array}{c}\text { Standard Deviation } \\
(\text { STDEV })\end{array}$ & $\begin{array}{c}\text { TStatistics } \\
(\mathrm{O} / \mathrm{STDEV})\end{array}$ & P Value \\
\hline $\begin{array}{l}\text { Employee Engagement => Job } \\
\text { Satisfaction => Organizational }\end{array}$ & -0.002 & -0.001 & 0.013 & 0.187 & 0.852 \\
Commitment & & & & & \\
\hline $\begin{array}{l}\text { Emotional Intelligence => Job } \\
\text { Satisfaction => Organizational }\end{array}$ & 0.026 & 0.026 & 0.020 & 1.266 & 0.206 \\
Commitment & & & & & \\
\hline
\end{tabular}

Table 3 shows that the $\mathrm{P}$ Value> 0.05 , so this shows that the relationship between employee involvement and organizational commitment cannot be mediated by the job satisfaction variable. So that the sixth hypothesis which states that the relationship between employee involvement and organizational commitment can be mediated by job satisfaction, so that the sixth hypothesis is rejected.
The results of the analysis also show that the relationship between emotional intelligence and organizational commitment cannot be mediated by job satisfaction. So the seventh hypothesis which states that the relationship between emotional intelligence and organizational commitment can be mediated by job satisfaction, so that the sixth hypothesis is rejected. Employees have been working with enthusiasm and even in the morning are mentally prepared. The work 
that has been done has inspired them in their lives. Employee engagement in the work makes employees feel that the work they are doing has a large enough responsibility and ultimately fosters a sense of satisfaction with the work they have.

Employees have not been able to control emotional intelligence, employees have not been able to accept criticism from other people while working. Besides that employees have not been able to control the emotional inside of employees, this inability to control emotional intelligence has an impact on their sense of belonging to the company where they work.

The employee's inability to make employee job satisfaction at work is not achieved. Employees must be able to control their emotional intelligence at work, such as how to explain their own moods and abilities or shortcomings. When employees have good emotional intelligence, all responsibilities will be carried out properly so that it is in accordance with each individual's work target and job satisfaction can be achieved.

Job satisfaction does not affect employee commitment to work. This can indicate that employees have been working with dedication without questioning whether what has been done is in accordance with work targets or not. Employees also feel that what they receive in return for their work is appropriate. However, all of this does not affect their desire to remain part of the organization.

\section{CONCLUSION}

The research shows that employee involvement has an effect on job satisfaction. Job involvement is the level where employees engage with work and devote time and energy to their work and view work as an important part of their lives.

The results showed that emotional intelligence had no effect on job satisfaction. Emotional intelligence is the ability to understand other people, to motivate them, how they work, how to work hand in hand with intelligence. There needs to be assistance to employees in order to control the emotional side of employees.

The results showed that job satisfaction and emotional intelligence did not affect employee organizational commitment. When employees feel a match between what has been done and what is received in return, they will feel satisfaction at work. In addition, employees who are able to control emotional intelligence will increase their sense of belonging and thinking about staying at the company. This shows that so far the employee's organizational commitment does not need to be dragged anymore, but it needs to be a special concern for the organization because it could happen that so far employees have not felt satisfaction at work and the main concern is that employees are less able to control their emotional intelligence. This study also shows that the effect of employee interaction and intelligence on organizational commitment cannot be mediated by employee job satisfaction.

\section{REFERENCE}

Bagis, F., Darmawan, A., Hidayah, A., \& Ikhsani, M. M. (2020). The Influence of Leadership Style and Organizational Culture by Mediating Job Satisfaction on Organizational Commitment Case Study in Employees Of Islamic Education Institution. 6 (03), 616-620. http://dx.doi.org/10.29040/jiei.v6i3.1450

Bagis, F., Hartikasari, A. I., \& Pratama, B. C. (2018). DOES PROCEDURAL JUSTICE AND DISTRIBUTIVE JUSTICE MEDIATE THE EFFECT OF JOB SATISFACTION ON ORGANIZATIONAL COMMITMENT?: CASE STUDY OF EDUCATION INSTITUTION. 12(2), 6. https://doi.org/10.2991/amca-18.2018.93

Bagis, F., Pratama, B. C., \& Kharismasyah, A. Y. (2019). PENGARUH DISIPLIN KERJA, KOMITMEN ORGANISASI DAN KEPUASAN KERJA TERHADAP KINERJA KARYAWAN STUDI KASUS INSTITUSI PENDIDIKAN. Jurnal Manajemen, 13(2), 6.

Bakker, M. P., Leiter, Arnold B. (2010). Work Engagement: A Handbook of Essential Theory and Research. New York: Psychology Press.

Chin, W. W. (1998). The Partial Least Squares Aproach to Structural Equation Modeling. Modern Methods for Business Research. 295 336.

Gardner, H. (2013). Multiple Intelegences, Kecerdasan Majemukk Teori dalam Praktik. Tangerang Selatan. Interaksara.

Ghozali, Imam, H. L. (2015). Konsep, Teknik, Aplikasi Menggunakan Smart PLS 3.0 Untuk Penelitian Empiris. BP Undip. Semarang.

Goleman, D. (2005). Emotional Intelligence Untuk Mencapai Puncak Prestasi, Alih Bahasa: Alex Tri K.W, PT. Gramedia Pustaka Utama, Jakarta. 
Mathis, R, J., Jackson. (2011). Human Resources Management. 13thEdition. USA: South Western Cengage Learning.

Robbins, S. P. (2006). Perilaku Organisasi. Edisi kesepuluh. Jakarta: PT Indeks Kelompok Gramedia.

S Taylor, A. M. (2014). Armstrong's Handbook of Human Resource Management. 13th Edition. Ashford Colour Press Ltd.

Sari, A. P., Senen, S. H., \& Masharyono, M. (2019). Studi Komitmen Organisasi Karyawan Bank: Peran Job Involvement Dan Kepuasan Kerja. Strategic : Jurnal Pendidikan Manajemen Bisnis, 19(1), 7-18.
Schaufeli, W. B, B., A. (2003). UWES-Utrecht work engagement scale. Preliminary Manual (Version 1). Utrecht University: Occupational Health Psychology Unit, Utrecht/Valencia.

Snell, S, B., G. (2013). Snell, S. and Bohlander, G. Managing Human Resources. 16th edn. South Western: Cengange Learning.

https://doi.org/10.17509/strategic.v19i1.17670 